症 例

悪性リンパ腫治療後に罹患した組織型の異なる三重肺癌の一例

\author{
安達 剛弘*1, 佐野功*1, 橋本慎太郎*1 \\ 土肥良一郎*1, 谷口 英樹*1, 重松 和人*2
}

\begin{abstract}
要旨
症例は 86 歳男性．悪性リンパ腫再発にて治療後，右上葉の part-solid nodule に対し胸腔鏡下肺部分切除を施行. $8 \mathrm{~mm}$ 大の腺癌であり, pStage IA で内科にて経過観察となった。術後 2 年して肺切除断端部近傍に腫瘤影を指摘され，フォロー CT で増大傾向を認めた. 腫瘤は $5 \mathrm{~cm}$ 大に増大し, 下葉にも結節を認めた. 局所再発が疑われたが SCC や CYFRA などの腫 瘍マーカーが上昇しており，原発性肺癌の可能性も考えられたため手術の方針とした． 右上葉切除，下葉部分切除を行った ところ断端部腫瘤は扁平上皮癌, 下葉腫瘤は小細胞癌であり，異時性三重肺癌の診断となった，三重肺癌はこれまでも報告 されているが組織型が異なり, 更に悪性リンパ腫治療後の二次癌による三重肺癌が示唆される様な症例は非常に稀である.
\end{abstract}

索引用語：三重肺癌, 二次癌

triple lung cancer, secondary malignancy

症例

症 例: 86 歳 男性.

主 訴: 胸部異常陰影.

現病歴：びまん性大細胞性リンパ腫 (Diffuse large cell lymphoma, 以下 DLBCL), 滤胞性リンパ腫（Folicullar lymphoma, 以下 FL) に対して当院血液内科でフォロー 中. $\mathrm{X}-2$ 年にフォロー CT で右上葉に増大する partsolid nodule を指摘され原発性肺癌の疑いとなり, 当科に て胸腔鏡下右上葉部分切除術, リンパ節サンプリング （\#4R，\#10）を施行した。病理病期 T1aN0M0, Stage IA (第 7 版)であった。 その後リンパ腫再発に対して化学療 法を施行されたが, X 年に右上葉部分切除断端近傍に結 節影を認めた。約半年間の経過観察で増大傾向があり右 下葉にも結節影が認められたため, 診断・治療目的に当 科紹介となった。

\footnotetext{
${ }^{* 1}$ 日本赤十字社長崎原爆病院呼吸器外科

*2同 病理部

原稿受付 2018年 2 月23日

原稿採択 2018年 5 月 12 日

本論文の要旨は第 49 回日本胸部外科学会九州地方会総会 (鹿 児島）にて発表した。
}

既往歴：DLBCL, FL に対して化学放射線療法歴あり. 原爆による被曝歴あり。

(RB : Rituximab, Bendamstine, EPOCH-R : VP-16, VCR, DXR, PSL, CPA, Rituximab など). 他 B 型肝炎, 高血圧症, 狭心症.

生活歴：喫煙歴 20 本/日, 16 歳から 80 歳まで BI： 1280.

粉塵暴露歴なし 被曝歴あり.

入院時現症：身長 $161 \mathrm{~cm}$ 体重 $67 \mathrm{~kg}$ PS0.

発熱なし BP 122/66 mmHg HR 59 bpm $\mathrm{SpO}_{2}$ 97\%（室 内吸入下).

頸 部：表在リンパ節腫脹なし 胸部; 呼吸音清, crackle（－）心雑音なし.

腹 部: 平坦, 軟, 圧痛なし.

血液検査所見 : CRP $1.02 \mathrm{mg} / \mathrm{dl}$ と軽度上昇, Cre 1.17 $\mathrm{mg} / \mathrm{dl}$ と上昇あり。腫痬マーカーは CYFRA $6.3 \mathrm{ng} / \mathrm{ml}$, CEA $89.7 \mathrm{ng} / \mathrm{ml}$, SCC $4.0 \mathrm{ng} / \mathrm{ml}$ ，シアリル LeX-i 抗原 (SLX) $50 \mathrm{U} / \mathrm{ml}$ と上昇していた. ProGRP は陰性であっ た，その他血算, 生化学検查で特記すべき所見なし。

生理機能検查: 心電図 脈拍 67 回/分, 洞調律, 右脚 ブロック, ST-T 変化なし.

呼吸機能検查 : VC $2810 \mathrm{ml}, \% \mathrm{VC} 98 \%, \mathrm{FEV}_{1.0} 1.95$ 1, \% 


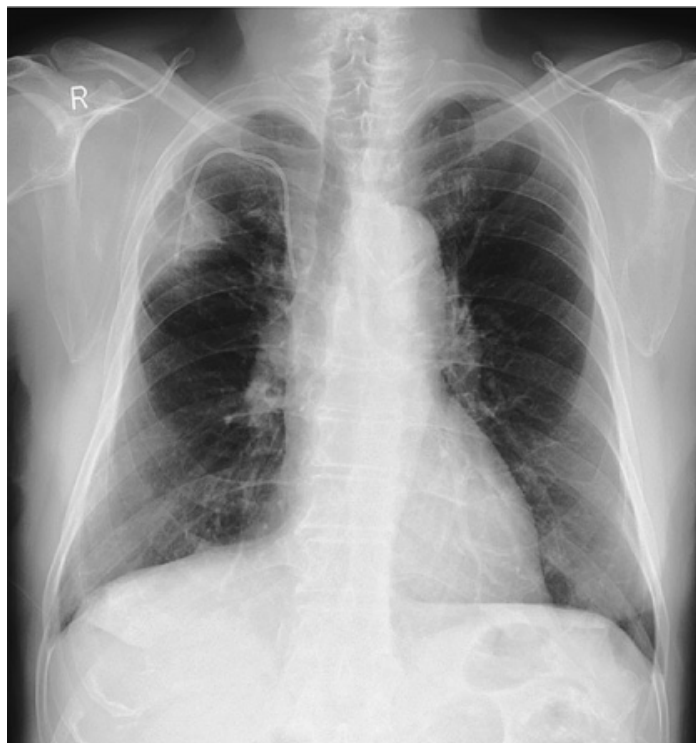

Fig. 1

Chest radiograph shows a nodular shadow in the right upper lung field. A central venous access device was implanted to administer chemotherapy against malignant lymphoma.

$\mathrm{FEV}_{1.0} 69 \%$.

$\%$ DLCO $77 \%$.

胸部 X 線：(Fig. 1) 右上肺野, staple 近傍に腫瘤影あ り.

胸部 CT：初回手術前の CTでは右上葉に $10 \mathrm{~mm}$ 程 度の part-solid nodule を認めた(Fig. 2). その後, 右上葉 部分切除断端近傍に腫瘤影を認めた。フォローCTで明 らかに増大傾向を示した，右肺門，気管分岐下リンパ節 もやや腫大していた。 また右下葉にも新たな結節影を認 めた（Fig. 3a〜c）

PET-CT：（Fig. 3d）右上葉断端近傍の腫瘤に $\mathrm{SUV}_{\text {max }}$ 22.373-29.198 と著明な集積を認めた。また右下葉結節は 軽度の集積であった，右肺門，気管分岐下のリンパ節に は経度の集積を認めた。

臨床経過：初回手術では年龄や合併症, 未梢病変であ ることを考慮して術式として肺部分切除, リンパ節サン プリングを選択した。 今回は経過から肺癌術後断端再発 が疑われるが, SCC などの腫痬マーカーが上昇していた ことや右下葉結節は不整形陰影であり原発性肺癌の可能 性も示唆された，放射線治療をするには照射野が広くな る可能性があり，また当科紹介された時点では $5 \mathrm{~cm}$ 大 で腫瘍が大きく気道内出血の可能性もあるため手術の方

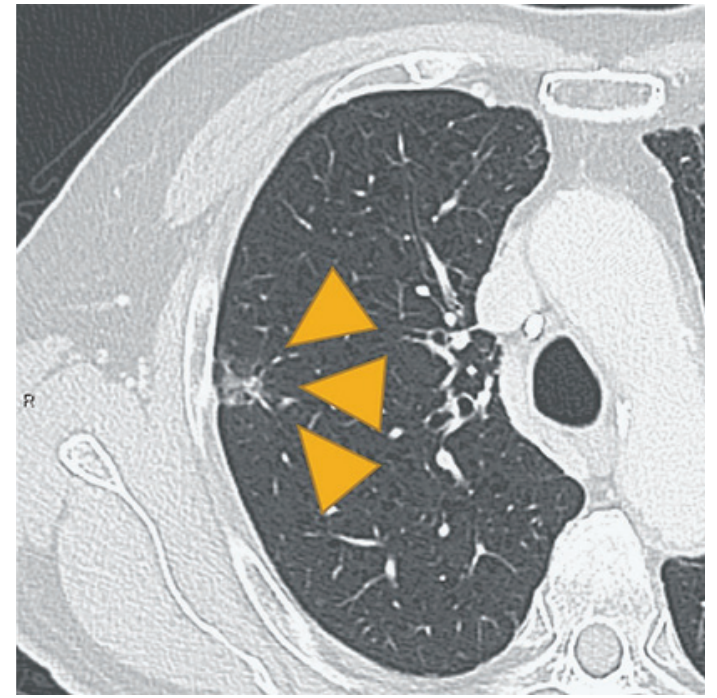

Fig. 2

CT shows a part-solid nodule in the right upper lobe.

針とし, 右上葉切除, リンパ節郭清 ND1b, 右下葉部分切 除を施行した。

手術所見：第 7 肋間中腋窩腺より $11.5 \mathrm{~mm}$ ポートを 挿入した。明らかな播種や胸水は認めなかった。胸腔洗 浄細胞診を施行。上葉は前回手術による癒着を広範に認 めたため第 8 肋間後腋窩腺にポートを追加, 第 4 肋間で $8 \mathrm{~cm}$ の開胸としたが, 縦隔側に強固な癒着があり開胸創 を延長した。葉間処理と血管処理を行い，著明に腫大し ていた\#10 を郭清して上葉気管支を切離して上葉切除と リンパ節郭清 ND1b を終えた。また下葉肺底区の結節は 触知可能で肺部分切除を施行した。

\section{病理組織所見 :}

初回手術時

右上葉

Adenocarcinoma, right upper lung, acinar (Fig. 4a). pTla ; $8 \times 5 \times 5 \mathrm{~mm}$ in size, pl0, Ly0, V0 (EVG), R0 $(8 \mathrm{~mm})$, pNOM0, Stage IA.

右上葉部分切除標本は長径 $8 \mathrm{~mm}$ 大の腺房型主体の腺 癌でリンパ節転移は明らかでなく病理病期 TlaN0M0 で あったままた EGFR 遺伝子変異, ALK 免疫染色はともに 陰性であった。断端はおおよそ $8 \mathrm{~mm}$ 程度で院性と判断 した。

\section{今回手術時}

右上葉

Squamous cell carcinoma, right upper lung, lepidic 


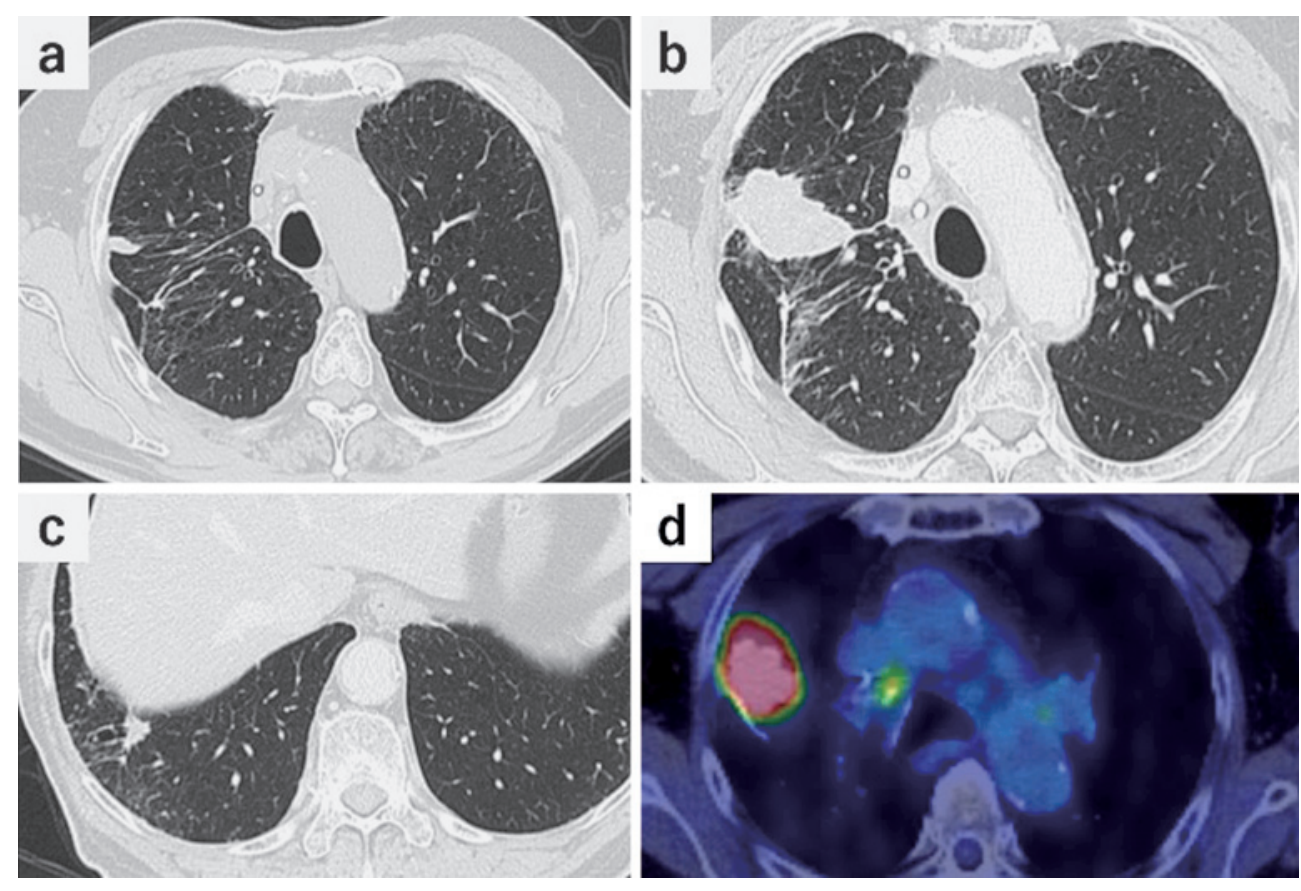

Fig. 3

CT shows a new nodule near the stump at the right upper lobe (a) showing growth (b). A new nodular lesion at the right lower lobe (c). PET shows abnormal uptake in the stump of the right upper lobe (d). The SUVmax range of the nodule was 22.373-29.198.

growth $0 \%$ (Fig. 4b).

pT2b ; $55 \times 35 \times 50 \mathrm{~mm}$ in size, pl1, G2, Ly1, V1, Ro/ br $(-)$, pa $(-)$, pm0.

pN1\{10 (0/3), 11s (4/5), $12(6 / 8)\}$ M0, Stage IIB.

右下葉

Small cell carcinoma, right lower lung, lepidic growth 0\% (Fig. 4c, d).

pT2a ; $20 \times 15 \times 10 \mathrm{~mm}, \mathrm{pl} 2, \mathrm{G} 4, \mathrm{Ly} 1, \mathrm{~V} 1, \mathrm{R} 0, \mathrm{pm} 0$ pN0\{10 (0/3), 11s $(0 / 5), 12(0 / 8)\}$ M0, Stage IB.

IHs ; Synaptophysin $(+)$, Chromogranin A (+),

Structure of somatostatin receptor (SSTR) 2 (Score3).

今回の手術に抢ける右上葉断端近傍の腫瘍は角化を示 しており, napsin A (-), p40 (+), TTF-1 (-) であ り, 以上から扁平上皮癌と診断した。 また右下葉の結節 は免疫染色の結果などからも小細胞癌と考えられた. 開 胸時胸腔洗浄液の細胞診では Class V の小細胞癌を認め た. \#11, \#12 にリンパ節転移を認めたがいずれも扁平上 皮癌からの転移であった。

術後経過：術後 2 日目には胸腔ドレーンを抜去し, 6 日目に退院となった，術後補助化学療法は行わず, 内科 で経過観察とされていたが術後半年の CT で両肺に多発
肺内転移を来し BSC の方針となった.

$$
\text { 考察 }
$$

重複癌の定義は Martini らが提唱した定義 ${ }^{11}$ が一般的 に用いられている.組織型が同じ場合は各腫瘍の悪性度, 存在部位が異なること，それぞれが原発であることが条 件とされている，本症例では明らかに組織型が異なり， 三重肺癌と考えて問題ないと思われる。 また同時性, 異 時性について Moertel らは 6 力月以内の発生を同時性, それ以降を異時性としている2. 本症例は始めに罹患した 肺腺癌から 3 年近く経過して二重肺癌を発症しているこ とから異時性三重肺癌と考えられる。

多発肺癌の頻度は近年 CT などの画像診断の進歩もあ り増加傾向であり，日本胸部外科学会の報告では原発性 肺癌 38444 例中 1227 例（約 3.2\%）とされている3）。 また 三重肺癌の頻度はさまざまな報告があるが 0.1-0.14\% 程 度ではないかと推測されている ${ }^{4.7)}$. しかし組織型がそれ ぞれ異なる三重肺癌は非常に稀であり, 本症例の様に悪 性リンパ腫治療後の三重肺癌で本邦において論文化され ているのは Tokuchi ら ${ }^{8)}$ の報告以外ない.

多発肺癌の問題は診断に難渋する点とその治療方針で 


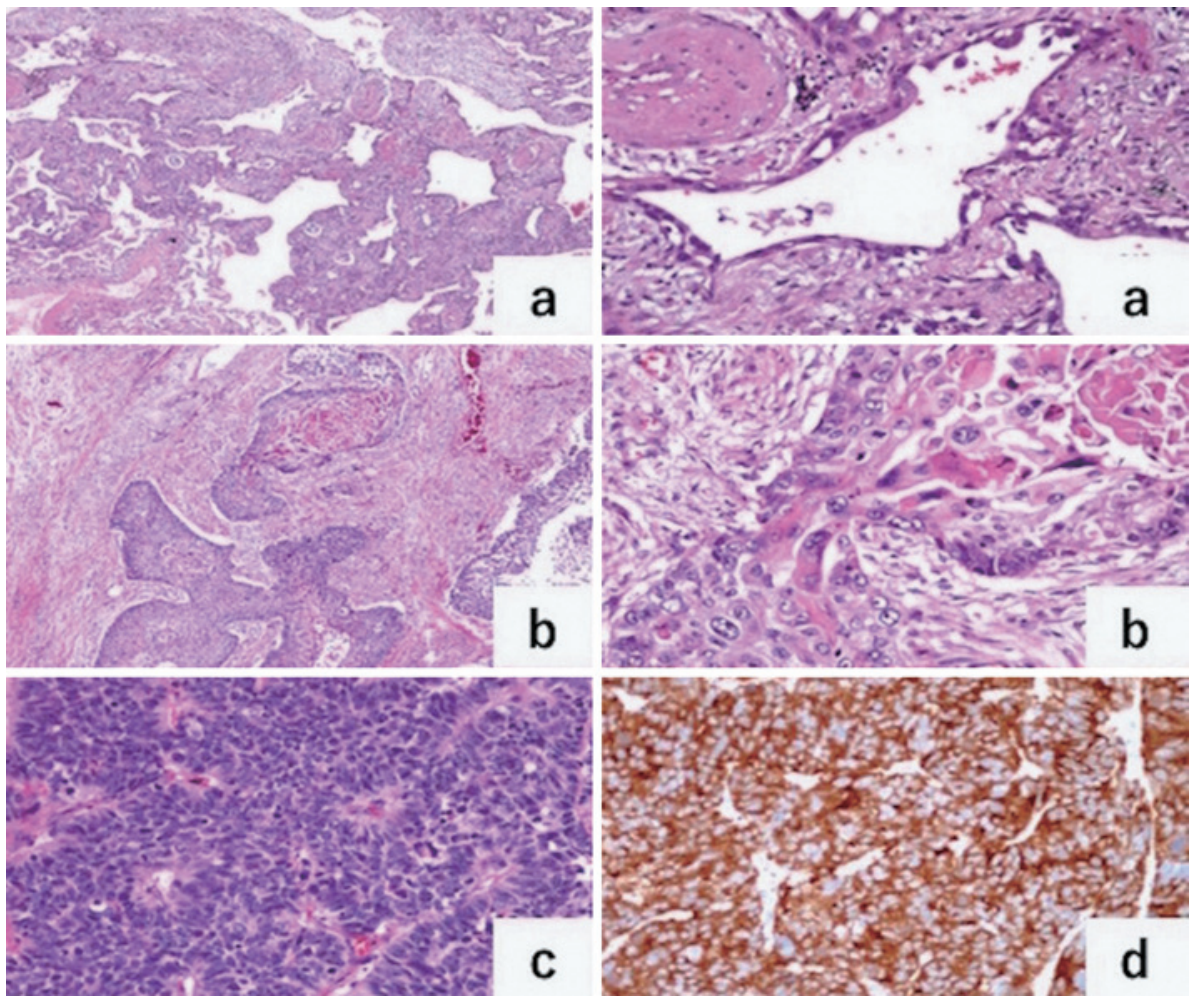

Fig. 4

a)

The right upper lobe on the first surgical resection. It was histologically diagnosed as adenocarcinoma with an acinar pattern.

b), c), d)

[b] shows the tumor of the right upper lobe and on surgical resection. [c], [d] also show the tumor on right lower lobe wedge resection at that time. [b] was histologically diagnosed as squamous cell carcinoma. Immunohistochemically, [d] was stained with synaptophysin, so the tumor in the right lower lobe was diagnosed as small cell carcinoma.

ある. 分子生物学的手法によって両者を鑑別する報告9, 10) もあるが, 日常臨床では応用されておらず Martini らの 基準 ${ }^{1)}$ を参考にすることが多い. 多発肺癌であれば再発や 肺転移よりも予後良好とされるため ${ }^{11)}$, 根治性を考虑し た術式が選択されるべきである。一方で Koike らは早期 肺癌において区域切除や楔状切除などの縮小手術の OS やDFSが葉切除に対して非劣勢であったことを報告し ており ${ }^{12)}$, 積極的に縮小手術を選択することで術後肺機 能を温存し, 異時性に多発肺癌が発生した場合でも選択 肢を拡げることができると考える.

また本症例は二次癌との関連も考察される．放射線や 化学療法による悪性リンパ腫などの血液疾患, 固形癌の 増加は既に知られている。 二次癌について Morton らの 報告 ${ }^{13)}$ では化学療法や放射線療法を受けている患者では 肺癌に罹患する割合が有位に高くなっていることが示さ
れている．また悪性リンパ腫治療後少なくとも 1 年以上 経過して肺癌に罹患した患者では慢性リンパ性白血病 や，FLの治療後で有意に発癌の標準化罹患率が高く なっていることも示されている.

本症例は原爆による被曝歴があり, また DLBCL や FL に対して Rituximabを含めた化学療法を施行された経 緯があることから二次癌の可能性は十分に示唆されると 思われる。

\section{結語}

悪性リンパ腫治療後に罹患した組織型の異なる三重肺 癌の一例を経験した。組織型の異なる三重肺癌は非常に 稀であるが診断と治療戦略に難渋する。多発肺癌が鑑別 に挙がる場合, 患者の全身状態や肺機能と根治性を考慮 した術式が望まれる。 


\section{利益相反}

本論文について申告する利益相反はない.

\section{文献}

1. Martini N, Melamed MR. Multiple primary lung cancers. J Thorac Cardiovasc Surg 1975; 70: 606-12.

2. Moertel CG. Multiple primary malignant neoplasms: historical perspectives. Cancer 1977; 40: 1786-92.

3. Committee for Scientific Affairs, The Japanese Association for Thoracic Surgery, Masuda M, Okumura M, Doki $\mathrm{Y}$, Endo S, et al. Thoracic and cardiovascular surgery in Japan during 2014. Annual report by The Japanese Association for Thoracic Surgery. Gen Thorac Cardiovasc Surg 2016; 64: 665-97.

4. 杉尾賢二, 宮脇美千代, 小副川敦, 橋本崇史, 安部美幸. 同時性・異時性重複がんの実態と治療戦略 肺癌. 臨外 2015; 70: 1341-5.

5. 古武彌宏, 岡田貴浩, 尹 亨彦, 末岐博文, 奥村明之進, 中川勝裕, 他. 肺多発癌の診断と治療. 肺癌 1991; 31: 416.

6. 辰巳明利, 北野司久, 黄 政龍, 田中文啓, 康 天志. 異 時性 3 重複肺癌の 1 例と当科における肺多発癌の検討. 気管支学 1991; 13: 275-81.

7. 谷村繁雄, 梶田正文, 土屋了介, 宮沢直人, 成毛韶夫, 米 山武志, 他. 多発性原発性肺癌の診断・治療および予後.
肺癌 1982; 22: 45-52.

8. Tokuchi Y, Kamachi M, Harada M, Hasegawa M, Mishina T, Yamashiro K, et al. Synchronous triple lung cancers after treatment for non-Hodgkin's lymphoma: metachronous quadruple cancers. Intern Med 2003; 42: $1031-4$.

9. Mitsudomi T, Yatabe Y, Koshikawa T, Hatooka S, Shinoda M, Suyama M, et al. Mutations of the P53 tumor suppressor gene as clonal marker for multiple primary lung cancers. J Thorac Cardiovasc Surg 1997; 114: 354-60.

10. Ichinose Y, Hara N, Ohta M. Synchronous lung cancers defined by deoxyribonucleic acid flow cytometry. J Thorac Cardiovasc Surg 1991; 102: 418-24.

11. Pairolero PC, Williams DE, Bergstralh EJ, Piehler JM, Bernatz PE, Payne WS. Postsurgical Stage I bronchogenic carcinoma: morbid implications of recurrent disease. Ann Thorac Surg 1984; 38: 331-8.

12. Koike T, Yamato Y, Yoshiya K, Kina S, Shimoyama T, Suzuki R, et al. Criteria for intentional limited pulmonary resection in cT1N0M0 peripheral lung cancer. Jpn J Thorac Cardiovasc Surg 2003; 51: 515-9.

13. Morton LM, Curtis RE, Linet MS, Bluhm EC, Tucker MA, Caporaso N, et al. Second malignancy risks after non Hodgkin's lymphoma and chronic lymphocytic leukemia: differences by lymphoma subtype. J Clin Oncol 2010; 28: 4935-44. 


\title{
A case of triple lung cancer with three pathological types after treatment of malignant lymphoma
}

\author{
Masahiro Adachi ${ }^{* 1}$, Isao Sano ${ }^{* 1}$, Shintaro Hashimoto ${ }^{* 1}$ \\ Ryoichirou Doi ${ }^{* 1}$, Hideki Taniguchi ${ }^{* 1}$, Kazuto Shigematsu*2 \\ ${ }^{* 1}$ Department of General and Thoracic Surgery, ${ }^{* 2}$ Department of Pathology, \\ Japanese Red Cross Nagasaki Genbaku Hospital, Nagasaki, Japan
}

A 86-year-old man had been pointed out as showing a part-solid nodule in the right upper lobe, which had been diagnosed as malignant lymphoma (DLBCL, FL) and treated. He underwent right upper lobe wedge resection. Pathological findings revealed the nodule to be adenocarcinoma. Two years later, CT showed a nodular lesion near the stump in the right upper lobe and another nodule in the right lower lobe. The right upper lobe nodule had grown, considered to be recurrence at the stump. However the tumor markers SCC and CYFRA slightly increased. Thus, the tumors were suggested to be primary lung cancers. Right upper lobectomy and lower lobe wedge resection were performed. Pathological findings revealed the nodule near the stump to be squamous cell carcinoma and the nodule of the right lower nodule to be small cell carcinoma.

Metachronous multiple primary lung cancers with three pathological types after treatment of malignant lymphoma have rarely been reported. We report our experience along with a literature review.

(C) The Japanese Association for Chest Surgery (JACS) 